\title{
Toward the Community-based Sustainable Marine Tourism: Identifying the Impact of Tourism Development in Karimunjawa Island
}

Atika Wijaya, Suwito Eko Pramono, Inaya Sari Melati, Norol Hamiza Zamzuri, Mohd. Hafiz Hanafiah, Ayu Rohaidah Ghazali

To Link this Article: http://dx.doi.org/10.6007/IJARBSS/v11-i5/9924

DOI:10.6007/IJARBSS/v11-i5/9924

Received: 10 March 2021, Revised: 14 April 2021, Accepted: 30 April 2021

Published Online: 17 May 2021

In-Text Citation: (Wijaya et al., 2021)

To Cite this Article: Wijaya, A., Pramono, S. E., Melati, I. S., Zamzuri, N. H., Hanafiah, M. H., \& Ghazali, A. R. (2021). Toward the Community-based Sustainable Marine Tourism. International Journal of Academic Research in Business and Social Sciences, 11(5), 275-288.

Copyright: (C) 2021 The Author(s)

Published by Human Resource Management Academic Research Society (www.hrmars.com) This article is published under the Creative Commons Attribution (CC BY 4.0) license. Anyone may reproduce, distribute, translate and create derivative works of this article (for both commercial and non-commercial purposes), subject to full attribution to the original publication and authors. The full terms of this license may be seen at: http://creativecommons.org/licences/by/4.0/legalcode

Vol. 11, No. 5, 2021, Pg. 275 - 288

Full Terms \& Conditions of access and use can be found at http://hrmars.com/index.php/pages/detail/publication-ethics 


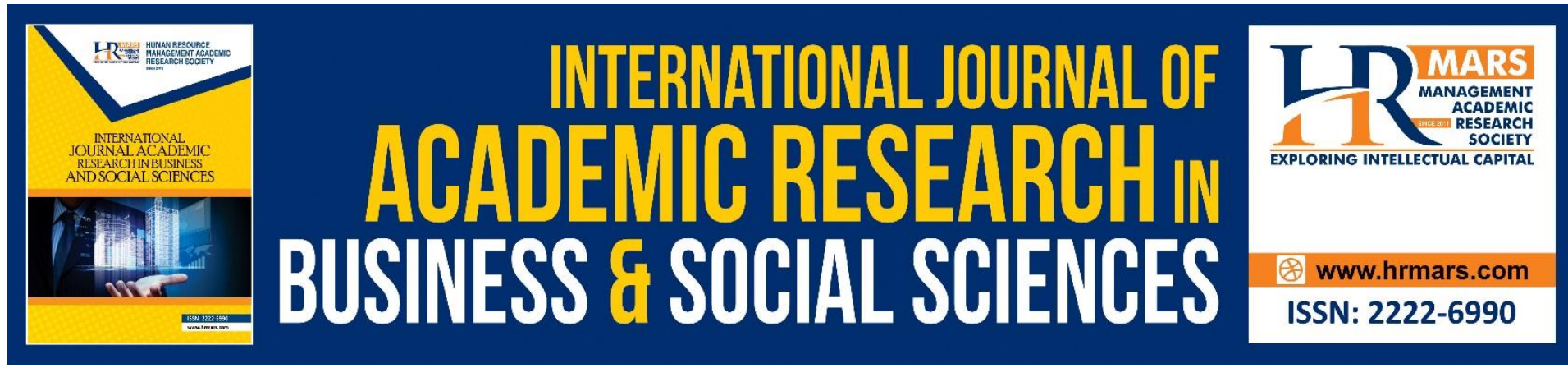

\title{
Toward the Community-based Sustainable Marine Tourism: Identifying the Impact of Tourism Development in Karimunjawa Island
}

\author{
Atika Wijaya ${ }^{1}$, Suwito Eko Pramono ${ }^{1}$, Inaya Sari Melati ${ }^{1}$, Norol \\ Hamiza Zamzuri², Mohd. Hafiz Hanafiah², Ayu Rohaidah \\ Ghazali ${ }^{2}$ \\ ${ }^{1}$ Universitas Negeri Semarang, Indonesia, ${ }^{2}$ Universiti Teknologi MARA, Shah Alam, Malaysia \\ Email: atika.wijaya@mail.unnes.ac.id
}

\begin{abstract}
This paper aims to assess the impact of conventional tourism development in Karimunjawa Island in Indonesia. This paper considers the impact from the perspective of local people in three sustainable tourism development aspects: economic, environmental, and sociocultural. In addition, this paper explores the perspective of the local people to support the initiation of community-based sustainable marine tourism in Karimunjawa Island, Indonesia. This paper employed mixed methods, and the data were collected through a survey, interviews, observation, and documents analysis. This paper found that tourism has brought positive economic impact while in other aspects, it produces negative impacts such as environmental damage to marine biodiversity and unsuitable tourist behaviour that clashes with the local norms and values. Therefore, this paper proposes the application of Penta helix policy and collaborative strategy between community, local government, academics, media, and tourism business actors in order to develop community-based sustainable marine tourism in Karimunjawa island.
\end{abstract}

Keywords: Community, Environmental Conservation, Karimunjawa Island, Marine Tourism, Sustainable Tourism

\section{Introduction}

Tourism is one of the strategic sectors in the economic development of a region. Tourism is no longer a journey activity for leisure, but also a social and economic activity which is inseparable from people's life. It is undeniable that tourism can attract tourists, create more job employment opportunities, all of which lead to improving the people's economy (Pitana \& Gayatri, 2005). Also, tourism is an industry that consists of vast business variety and multiple complexes (Pendit, 2006). In addition to that, the tourism sector certainly brings a beneficial impact on society and its regional economy. For countries that depend on its natural landscape and the richness of biodiversity, tourism activities provide job opportunities, enhancing the income of local people, improving life quality, and even stimulate other sectors (Laksono \& Mussadun, 2014; Tatarusanu, 2016). Since then, the 
tourism industry plays a vital role in economic development for some countries, and tourism became their main contributor toward national income (Pitana \& Gayatri, 2005).

However, at the same time, tourism activities change the dynamics in society and trigger unfavourable social and cultural impact. Pitana \& Gayatri (2005) stated that the interaction between the tourists and the host might influence the host community on the wrong path. Many researchers have studied the impacts of tourism in the last decades. In order to assess the impacts of tourism, most studies have identified the positive and negative impacts on tourism from three aspects: economic, sociocultural, and environmental (García, Vázquez, \& Macías, 2015). From these aspects, we could see the quality of life of local communities who live in surrounding tourist destinations.

Generally, the economic impacts are a major impact in tourism as many studies on tourism discussed the positive and negative economic impacts. As mentioned above, tourism is open job employment for local people and adds the source of income for them (García et al., 2015). Liu et al. (2012) in their study found that the community, particularly the household unit, get direct and indirect financial benefit from tourism. At the same time, tourism encourages the local government to improve the infrastructure and facilities in the destination. However, the negative impact is that it gradually increases the living standard in the region. Therefore, tourism also creates a wider economic gap among local people because not all local people could take the opportunity in the tourism industry and take economic benefit from it.

As mentioned above, tourism has a serious effect on the dynamics of society and becomes a trigger to change the sociocultural aspect of a community. Interaction between the tourists and the host may affect positively and negatively. Tourism become an opportunity to introduce the richness of local culture and arts, raise awareness in preserving historic buildings and cultural sites, and at the end tourism improve the quality of life of the community (García et al., 2015; Eslami et al., 2019). On the other hand, unfortunately, tourism also stimulates negative impacts such as criminal cases, creating dense crowds, traffic jams, and parking problems. Some studies also found that tourism caused drug use, alcohol consumption and even prostitution (García et al., 2015).

Not only has an impact on society, but tourism also has a negative impact on environmental sustainability. In the recent years, coastal and marine tourism growth stadily and increase the concern of its environmental sustainability (Gladstone, Curley, \& Shokri, 2013). The negative effects of tourism activities towards the environment includes the damage of coral reef due to diving activities in small island tourism (Campbell, Kartawijaya, Yulianto, Prasetia, \& Clifton, 2013; Priyanto, 2016), the hotel construction in the tourist destination without considering environmental conservation, and pollution which resulted from tourists' activities (Laksono \& Mussadun, 2014). The conventional tourism development caused environmental degradation due to a lack of awareness from tourists and the local community (Puryono \& Suryanti, 2019). The intensity of tourism activities in coastal and marine environments led to habitat damage (Gladstone et al., 2013). Zhong et al (2011) reviewed the environmental impact of tourism in China and found that tourism put the environmental sustainability at high risk and severe damage, and therefore need the new insght on the reinforcement of tourism environment where tourism development should improve the environment and not the other way around. Tourism in Bali, for example, brings more positive impacts on economic and sociocultural, but unfavorable impacts on environmental aspects (Ernawati, Sudarmini, \& Sukmawati, 2018).

Despite those threats and risks, governments in many countries still depend on the tourism sector to develop their region in any means, particularly if those destinations possess limited economic resources. Nowadays, governments focus on developing small islands and rural 
areas as a tourism destination. These small islands tend to have a problem with poverty, low quality of human resources, low education, lag of development, and more. The local community in the small islands are mostly fishermen who are prone to poverty (Setiawan, Rijanta, \& Baiquni, 2017). Although people on the small island tend to have low education, they have local values that internalize through socialization in the family (Rochwulaningsih, 2015). Besides its environmental appearance, small islands also have a cultural and social richness of its society. On the other hand, these small islands have many potential marine resources and biodiversity which are interesting in being explored by tourists who were looking for something unique and exotic (Jones, Qiu, \& Santo, 2013).

Indonesia has many small islands with abundant marine resources and a variety of socialcultural aspects. Karimunjawa Island in Central Java, Indonesia, is a famous tourist destination for both domestic and international tourists. Karimunjawa Island is also known as "Bali" of Java, which refers to a similar atmosphere as in Bali Island. Karimunjawa is a sub-district under the administration of Jepara Regency in Central Java, Indonesia. Karimunjawa sub-district has many small islands, and the main island is Karimunjawa Island. The area is under the protection of Karimunjawa National Park (KNP) which is well known as the first and essential maritime area for its conservation of marine biodiversity in Indonesia (Campbell et al., 2013). It also has a traditional village, rare wildlife, and plants, as well as several homestays. A study by Umardiono (2011) claimed that the biodiversity richness of Karimunjawa Island, together with the natural and cultural attractions was the main attributes that lead to international and domestic tourism demand.

Since Karimunjawa is well known to the tourists, some of the local people work in the tourism sector as a hotelier, tour guide, food service, etc. The local government continuously developed public facilities and infrastructure on the island to support tourism activities. Subsequently, tourism demand leads to uncontrolled and mass tourism activities. Due to massive tourist activities in the sea, the concern of biodiversity conservation is vital to preserve the sustainability of the maritime area. The rapid growth of hotels and resorts to accommodate the tourists' needs also contribute to the environmental damage in tourism island (Limbong \& Soetomo, 2014). The existence of coral reefs in Karimunjawa is not only important from a biological standpoint, but also socio-economic so that it needs to be managed wisely (Baskara, Hendarto, \& Susilowati, 2017; Kennedy et al., 2020). Although KNP already issued a policy to limit the visitors and undersea activity, this policy implementation also needs support from the local tourism business.

The sustainability of marine biodiversity in Karimunjawa Island became a serious concern for researchers in Indonesia and foreigners. KNP also manages and protects mangrove forest in Karimunjawa. Mangrove is also important for the Karimunjawa ecosystem as well as for humans from its wood, leaf, and it is used to make traditional medicine (Winata, Yuliana, \& Rusdiyanto, 2017). Many studies have been done on Karimunjawa Island in various aspects, including geographical aspects, social aspects, economic aspects, ecological aspects, and tourism aspects. However, little was known about social-economic aspects as well as sustainable tourism development in Karimunjawa Island. Therefore, this paper aims to identify the economic, social, and environmental impacts caused by conventional tourism development in Karimunjawa Island, Indonesia. This study focuses on the opinion of the local community as we understand that local people have their local knowledge and local wisdom on how to conserve the environment as their lives depend on the sustainability of the environment. The social and cultural values of the local community are supposed to be able 
to protect them from the negative impact of tourism. Moreover, this study highlights the importance of community participation in developing community-based sustainable marine.

\section{The Concept of Sustainable Tourism in Indonesia}

Tourism is a human phenomenon which means that tourism activities which are done by human influence on human life (Ardika, 2018). Tourism is also a driving force for social and cultural change in society and is considered a strategic sector that can improve the economy of a region. However, the impact of tourism is equally important. In some cases, tourism marginalizes the local community itself and causes other negative impacts on society. Then, the trend of tourism in the world changed, and economic growth was not the main issue anymore. The impact of tourism activities such as environmental damage and degradation of the social life of local communities has influenced the changing paradigm of tourism management in the world. The duality of tourism needs to understand by policymakers and community, at one point, tourism is filled with individualistic, hedonistic, and even exploitative purposes, but on the other one, tourism is one kind of education channel, crosscultural engagement, ecological appreciation, and even spiritual development (HigginsDesbiolles, 2017). Therefore, the paradigm of tourism is supposed to base on this duality.

Since the launch of the Burtland Report in 1987 about the notion of sustainable development, sustainable tourism has become the dominant paradigm in tourism development and management (Ruhanen et al., 2015). Followed by the formulation of Sustainable Development Goals (SDGs) by the United Nation, the emergence of sustainable tourism is translated into measurable indicators which emphasize the balance between environment, economic and social aspects (Ardika, 2018: 60). The study objectives are in line with the United Nations World Tourism Organization (UNWTO) refers to three SDG2030 goals. It is important that in the tourism sector, marine tourism is the largest tourism segment. Therefore, conservation efforts and the preservation of marine resources become an important agenda in realizing sustainable tourism.

The core idea of sustainable tourism is a balance between the environmental, economic, and social aspects of human life. Figure 1 illustrates the interrelation between three aspects (planet, profit, and people) in which balancing it is the concept of sustainable tourism. UNWTO describes the indicators of sustainable tourism as follows (in Ardika, 2018: 60):

i.Make optimal use of natural resources which are key elements in tourism development, maintain the ecological processes needed, and conserve natural resources and biodiversity.

ii.Respect the socio-cultural noble values of the local community, participate in preserving cultural heritage and traditional values, and contribute to the creation of mutual understanding and tolerance among cultures.

iii.Ensure long-term economic operations, provide equitable socio-economic benefits to all stakeholders, including stable employment and employment opportunities and social services to local communities, and contribute to poverty alleviation.

The previous paradigm of tourism strongly focuses on economic growth and at some point neglected the limitation of ecological resources and social resources (Higgins-Desbiolles, 2017). Besides that, other challenges that affected the tourism industry nowadays are climate change, political instability, and the vulnerable ecology of natural resources (Budeanu \& et al., 2015). Therefore, the emergence of a sustainable tourism notion is needed to address today's complex world problem. One important aspect to support sustainable tourism development is the quality of life of local people in the tourism destination. It is undeniable that the implementation of sustainable tourism needs the support from the local 
community. The local community will have evaluated costs or benefits of tourism in terms of environmental, socio cultural, and economic impacts that affect their quality of life (Eslami et al., 2019). Moreover, Eslami et. al (2019) found that positive impacts of tourism development could outweigh the perception of negative impacts and therefore the community will support the sustainable tourism development.

It has been three decades since tourism became an important sector for Indonesia as the government issued a policy to regulate tourism. The first policy is Law number nine in the year 1990 about tourism. This policy includes important aspects of the operationalization of tourism and elaborates on various types and functions of many kinds of activities in the tourism industry (Ardika, 2018: 17). The perspective of this policy was mainly on economic growth and the number of tourists by building a lot of infrastructure and physical facilities. Following the change in the global tourism paradigm, Indonesia also concerns about sustaining the tourism sector that suits the international market. The national scheme of tourism development based on the national long-term plan $2010-2025$ focuses on four main areas: tourism destination, tourism industry, tourism marketing, and tourism institutionalization (in Ardika, 2018). The last aspect refers to the development of human resources capable of managing tourism in each region. The Indonesian government improves the awareness of sustainable tourism development by initiating the concept of sustainable tourism in Indonesia.

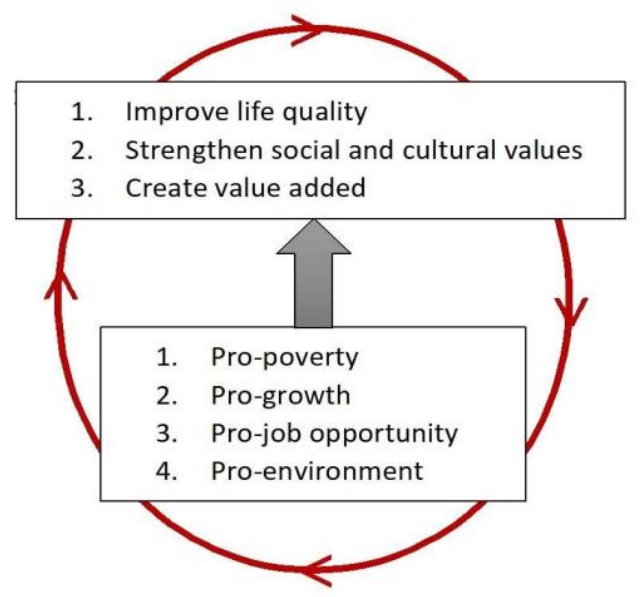

Fig. 1: The Concept of Sustainable Tourism in Indonesia (Ardika, 2018: 61).

Figure 1 illustrates the direction of tourism development in Indonesia. Tourism aims to improve the quality of life, both human and non-human, strengthen socio-cultural values, and create added value. These goals will be achieved if tourism activities and development plans take into account poverty alleviation, economic growth, creating jobs, and not neglecting the environment. All indicators work in one cycle and continuously influence each other. Priyanto \& Pirastyo (2019) stated that tourism also gave a positive impact on society's organizational system where people are more open and flexible to the change caused by the tourism sector.

The tourism development of Karimunjawa Island is not heavily reliant on its community. The local government does not have an integrated concept on the tourism development in Karimunjawa. Every actor has different interests and agenda. Nevertheless, Nugroho (2015) found that the role of stakeholders in developing tourism has not been optimal in helping people to take advantage of tourism opportunities and improve welfare. Therefore, the 
development of community-based sustainable marine tourism is important to encourage the realization of sustainable tourism in Indonesia, which aims to improve quality of life, strengthen social and cultural values, and create value-added. In this paper as our initial step, we identify the potential as well as the impacts that are faced by the local community in tourism destinations which resulted from the development of conventional tourism in Karimunjawa Island to these days.

\section{Method}

This study employed mixed methods by combining quantitative and qualitative approaches. The qualitative method is used as a research procedure that produces descriptions in the form of written or spoken words from people and observable behaviour (Moleong, 2014: 3) while the quantitative method is used as research to identify the patterns and regularities in nature (Moses \& Knutsen, 2012). This paper used descriptive quantitative analysis to narrate and illustrate the responses in the form of graphs and tables mainly to get nominal information about the demographic of respondents (Moses \& Knutsen, 2012; Nawawi, 2015). In addition, qualitative data is expected to understand the comprehensive meaning of events and their relation to certain situations, so that the data will be described in more depth about the impacts of conventional tourism on Karimunjawa Island.

This research setting is Karimunjawa Island, Central Java, Indonesia, based on some considerations. First, Karimunjawa Island is a unique tourism destination in small islands. The beautiful natural resources and biodiversity richness above water make both islands potential for the development of sustainable tourism. Second, the society in both islands has a variety of cultural backgrounds which is interesting to explore their local knowledge. Third, the current conventional tourism has impacted the physical environment and society in Karimunjawa.

The data collection in Karimunjawa Island was conducted in October 2020 which was delayed a few months due to the Covid-19 pandemic. After the initial lockdown was lifted, the data collection was executed via survey, interview, observation, and document analysis. First, a survey was distributed to 50 respondents of local people in Karimunjawa Island. In this research, we used a quota sampling technique. Quota sampling aims to determine samples from populations that have certain characteristics until they meet the desirable quorum (Hadi, 2004; Nurgiyantoro, Gunawan, \& Marzuki, 2002). In this technique, the number of population was not calculated but will be classified into groups (Hadi, 2004). We determine a quorum of 50 people to fill out the survey which consists of two groups of those who work in the tourism business sector and those who live in surrounding tourism attractions to find out local people's opinion about the impacts of conventional tourism in Karimunjawa Island. In addition to that, some limitations in the field during the covid-19 pandemic period, such as time restriction, human resources, and strict health protocol were supporting applied quota sampling. A total of 40 closed questions comprising 3 topics (i.e. 12 questions on economic impacts, 15 questions on social impacts, and 13 questions on environmental impacts) were asked to the respondents. The data display from quantitative data in the form of frequency distribution which shows frequency and percentage. Later on, the description and explanation from the qualitative data.

Second, interviews were conducted among the local community where they shared their experiences and perception living on Karimunjawa island. The interviews used semistructured interviews as the interviewers understood the topic and developed the questions during the survey. Interviews conducted during the respondents filling out the survey. Third, 
observations were conducted for ten days, along with surveys and interviews. From the results of observations, especially during the Covid-10 pandemic, the situation in Karimunjawa is indeed very quiet, with no tourists, and the tourism business actors hit the bottom. Fourth, we analyzed documents from the website of the District Government of Jepara and Karimunjawa National Park (KNP). The documents are the annual performance report 2019 and statistical data of tourism sector 2019. The process of data validation was undertaken continuously during the data collection.

\section{Results and Discussion}

\section{Demographics of Respondents and Tourists}

The total of respondents was 50 residents of Karimunjawa Island. The respondents consist of 29 males and 21 females. The respondents' age ranged from the youngest 19 years old to 53 years old the oldest. A total of 12 respondents were under 35 years old, and 38 people aged 35 years and over.

TABLE 1: Respondents Based on Occupation

\begin{tabular}{|l|c|c|}
\hline \multicolumn{1}{|c|}{ Occupation } & Total & Percentage (\%) \\
\hline Tourism sector & 28 & 56 \\
\hline Fisherman & 10 & 20 \\
\hline Housewives & 10 & 20 \\
\hline Others (i.e. handyman, civil servants) & 2 & 4 \\
\hline Total & 50 & 100 \\
\hline
\end{tabular}

There is a variety of occupations in the tourism sector that we found in Karimunjawa Island. Some of the respondents are the owner of a travel agent, tour guide, homestay owner or managers, restaurant owner, accessories seller, and rental owner of snorkelling pieces of stuff, motorcycles, cars, and boats. Since Karimunjawa became a tourist destination, many job opportunities were created for the local people.

TABLE 2: Respondents Based on Education Degree

\begin{tabular}{|l|c|c|}
\hline \multicolumn{1}{|c|}{ Level of Education } & Total & Percentage (\%) \\
\hline Elementary School & 19 & 38 \\
\hline Junior High School & 8 & 16 \\
\hline Senior High School & 21 & 42 \\
\hline Undergraduate & 2 & 4 \\
\hline Total & 50 & 100 \\
\hline
\end{tabular}

Educational facilities and infrastructure in Karimunjawa are yet inadequate. The Karimunjawa in Numbers year 2018, issued by the Central Bureau of Statistics of Jepara reported that this region only has 1 Junior High School and 1 Vocational High School. Therefore, to continue their studies in high school or university, Karimunjawa teenagers had to leave the island and migrate to the Jepara region.

Karimunjawa is a well-known tourism destination for Indonesian people and also foreigners. Every year this island never empties of visitors. We will present the number of tourists in recent years based on the data from KNP and the Tourism and Culture Office of Jepara District. In 2019, the number of domestic tourists visiting Karimunjawa is 137.653 people with 9.871 foreign tourists (Disparbud Jepara, 2019). 
TABLE 3: Number of tourists

\begin{tabular}{|l|c|c|c|c|c|}
\hline \multicolumn{1}{|c|}{ Type of tourists } & 2015 & 2016 & 2017 & 2018 & 2019 \\
\hline Domestic tourists & 4.380 & 7.074 & 7.840 & 8.152 & 6.272 \\
\hline Foreign tourists & 5.874 & 128 & 166 & 228 & 1.123 \\
\hline Total & 10.254 & 7.202 & 8.006 & 8.380 & 7.395 \\
\hline
\end{tabular}

Source: Karimunjawa National Park, 2020.

This number of tourists is the one who pays more tickets to visit the conservation area under the Karimunjawa National Park (KNP) territory.

\section{The Impact of Tourism Development in Karimunjawa}

We would like to elaborate on the result of this study about the impact of tourism in Karimunjawa. First, we will describe the economic impact, cultural impacts and the last is the environmental impact.

1) Economic impacts.

The results showed that of the 28 people who had businesses in the tourism sector, 11 people previously worked as fishermen before opening a tourism business. Being a fisherman cannot be ascertained that his income depends on the weather and other natural factors and requires a lot of capital to purchase diesel fuel. Thus, the first economic impact is an increase in job opportunities for the community. In the last 10 years, there have been many job opportunities in the tourism sector that can become additional jobs or substitute for their old jobs as fishermen when they are quiet. Such as travel agencies, souvenir shops, restaurants, tour guides, drivers, homestays/hotels, rental services for snorkeling/camping equipment, and car/motorbike rental services. As said by one of the informants $(\mathrm{H})$ below:

"...yes, I have a small business, a travel agency. Instead of being spectators in tourism, better we participate by opening a travel agency too. It has been 10 years since 2010 . At first, the initial capital is only an android phone, we take advantage of the internet signal that has entered this place and we promote Karimunjawa through social media such as Facebook, website."

Second, increasing income to meet daily needs. Their average income from the tourism business is approximately five million rupiahs per month. This is very profitable, especially because some of them do not need a lot of capital when starting this tourism business. From a monthly income of approximately five million rupiahs from the tourism business alone, they can meet their daily needs. Third, it can meet long-term or investment needs. In addition to meeting their daily needs and feeling sufficient, they use the profits from the tourism business for long-term investments. We asked them what economic benefits they get from tourism activities. Most of them answered for the children's school fees. Karimunjawa sub-district itself does not have many schools, there are only seven elementary schools, and one junior high school, while to continue their education to high school they have to go across the island to another sub-district in Jepara Regency which is on the mainland. It can be imagined that school fees for Karimunjawa teenagers are certainly more expensive, due to the cost of staying for their children to be close to school, pocket money, communication costs, and transportation if they want to return to Karimunjawa. Therefore, school fees are an investment requirement. In addition to that, tourism business owners use their income to expand their business both in terms of location and type of business.

From the data above, it can be concluded that Karimunjawa tourism activities have had more positive economic impacts than negative impacts at least up to these days. From tourism 
activities and the tourists, the local people of Karimunjawa can improve their income and welfare.

\section{2) Social impacts}

Pitana and Gayatri (2005) stated that tourism has two sides, one that can provide benefits and one that can also destroy the social structure of society itself. Tourism awareness is also marked by the presence of Pokdarwis (Tourism Awareness Groups) in their community.

First, the growth of organizations/associations in the field of tourism to accommodate people to become more aware of tourism. Most of the community, especially tourism business actors, have joined Pokdarwis. Through Pokdarwis, they get information about tourism, hospitality in the world of tourism, expand their network, organize tourism activities. Another benefit is gaining skills and knowledge through various training facilitated by both Pokdarwis and the local government. For example, homestay management training, English language training for tour guides, and training on making food that can be used as a special souvenir. As said by one of the informants (HS):

"Actually....there is (Pokdarwis) already here, but on hiatus. This is an opportunity for this pandemic. We want to strengthen everything. Pokdarwis are actors and also observers of the tourism development in Karimun. Some people are pokdarwis, who are observers of tourism. In here, there are many homestay inns, they join with Pokdarwis."

Second, introducing the art and culture of the community. Traveling is not just enjoying the beauty of nature but learning the culture of the local community. In Karimunjawa Island, there are Karimunjawa Village and Kemujan Village. Kemujan village itself is unique because their ancestors came from Bugis, Sulawesi who sailed to Madura but stopped at Karimunjawa. So that their traditions and culture are still closely related to Bugis culture. Few traditional dance studios are participating in tourism activities to perform in front of tourists.

Third, in addition to the two social impacts above which are positive, the third-social impact is about tourist behavior that is deemed not following community norms. Although the arrival of tourists is generally considered not to disturb the community, the community complained about several things that were done by tourists. Clothes are too open, especially foreign tourists often dress openly even though they are not in a coastal environment. At night, tourists who gather are often noisy and loud, thus disturbing residents' rest. The residents are worried that the children and adolescents of Karimunjawa village will adopt the behavior of tourists that are not following local norms.

Fourth, the increase in crime. For example, theft in a homestay and so on. The number of tourists and people passing by in Karimunjawa invites criminals to take advantage of tourists' negligence. Some informants who also homestay owners reported losing money and cell phones.

Fifth, consumptive behavior. The economic impact that increases people's income also encourages consumptive behavior. Out of the 50 respondents, 10 of them buy 3-5 electronic goods in one year. Meanwhile, the majority of respondents only buy 1-2 electronics a year. Although all answered that the reason they bought electronic goods was a necessity, it was undeniable that the purchase was based on the purchasing power that had increased from before. Especially with the increasingly busy tourism, internet and cell phones are no longer secondary goods but have become primary needs. 
3) Environmental impacts

Apart from the two impacts above, namely the economic impact and social impact, the impact of tourism activities on the environment can also affect the quality of life of the local community in the future. It is not impossible if there is no proper handling the beautiful environment will be damaged. To 50 respondents, we asked if there had been any changes in weather and air since the existence of tourism activities in Karumunjawa. The majority of them answered casually, while 17 people answered that they did not feel any changes. However, 1 person answered that there was a change, namely unpredictable weather.

First, there is a lot of plastic waste on the beach. Although some respondents said the environment was always clean, after digging further, they answered that there was a lot of plastic waste from beverage bottles and food wrappers. From the observations, the research team also saw that in the corners of the beach plastic bottles and food waste were lying around. There is also stranded garbage brought from the water currents. If this waste is not handled, it will disturb the cleanliness of the beach and of course the comfort of the tourists in the future. Especially on the beach is a place where tourists spend time to see the sunrise and sunset.

Second, the intensity of marine tourism activities, especially underwater activities such as snorkeling and diving, can damage marine ecosystems and biota such as coral reefs and various other marine biotas. Limited knowledge of tourists about snorkeling has the potential to cause damage to coral reefs. Often when doing snorkeling activities, tourists step on coral reefs and even take valuable coral reefs as souvenirs.

Third, the conversion of land for commercial tourism business. It is common knowledge that many businessmen or investors from outside the Karimunjawa area have participated in enlivening the development of tourism in Karimunjawa. The small islands with their resorts are owned by Jakarta.

Fourth, there is difficulty with clean water. Access to clean water sources is a problem for Karimunjawa residents. For a long time, they had difficulty getting clean water. According to residents, they had their water source that the residents could use. However, since many tourists came and then entered the local water company which then made pipes from the hotel to the hotel, in the end, it blocked access to water sources for the residents. The residents are forced to subscribe to PDAM water. Whereas before they could get it for free. More than $50 \%$ of the residents have to buy water to meet their clean water needs.

Fifth, this fifth impact is not completely negative as the four impacts mentioned above. Although tourism activities have the potential to damage the environment, on the other hand, there are positive things that can be obtained, namely increased environmental awareness. Because the beach in Karimunjawa is a community beach, business actors, together with residents and assisted by NGOs or from the Environmental Service or Karimunjawa National Park routinely work voluntarily cleaning the coastal environment. As explained by one of the informants (W):

"The residents who clean the beach together with the KNP officers. There is an HPI (Indonesian Tour Guide Association). So, everyone cleans the beach, but not every day. For daily cleaning, there is an employee on every beach to clean the beach.".

Nevertheless, business operators on the beach have also warned tourists not to litter and provide trash cans. The awareness to jointly protect the coastal environment cannot be separated from their awareness that the beach must be maintained if Karimunjawa tourism is to remain in the long term. 


\section{The Strategy of Community-based Sustainable Marine Tourism}

Community-based tourism is tourism that focuses on the community as the subject as well as the object of organizing tourism activities. So, the implementation of tourism is carried out with the principles of the community, by the community, and as much as possible for the community (Ardika, 2018: 23). For this reason, it is necessary to empower the community so that they can recognize the problems faced and identify their potential so that they can develop a form of tourism that suits their needs. Besides, strengthening tourism institutions is also important as a basis for tourism sustainability. The institution here concerns the role and involvement of stakeholders, namely government, academics, mass media, tourism business groups, and the community itself. This stakeholder linkage or it can be called the Penta helix is a collaborative effort that can support community-based sustainable tourism development. As we learn in Karimunjawa, that tourism is not well managed yet, the stakeholders walk individually.

First, academics play a role in increasing community capacity, indicators, to make academic papers or input for policy making. Meanwhile, the government plays a role in preparing work plans and targets, policies, data providers, regulations, and budgets. Business actors play a role in integrating the small business actors in Karimunjawa and connect it with the global market. The media play a role in advocacy, knowledge, raising awareness, dissemination, and monitoring. Finally, the community itself plays a role in evaluating tourism development plans in the region. The five elements in carrying out their respective roles contribute to the roles of other parties so that they complement each other. The tourism industry in Karimunjawa is currently still running independently like business actors, and the community has not been fully involved and supervised tourism in the area, except for the community who also owns a tourism business. By knowing the community's views on the impact of tourism in the area, a development plan can be carried out that involves and focuses the community as an object as well as the subject of marine tourism development in Karimunjawa.

\section{Conclusion}

From the research results that have been discussed in the previous sections, it can be concluded that the development of the tourism industry cannot be avoided. Tourism certainly has two sides that affect the lives of its people. If the risks and benefits can be identified, it will be easier to develop tourism. Karimunjawa has the potential to become a world-class tourist destination, but it needs to be maintained so that the environmental, economic, and social impacts that have been described previously are not getting worse and can be minimized. Community-based sustainable marine tourism development focuses on the role of communities as objects and subjects. By maintaining the economic, environmental, and social balance of these tourist destinations. The results of this study are expected to be a starting point or input for further research. This research still needs further study, especially related to the finalization of the community-based sustainable marine tourism model and its application stages. In addition, for local governments to be able to compile a clear road map for tourism development that involves stakeholders. For the community, to be more active in providing an assessment of tourism activities and if there is a potential for harm, it can be handled immediately. 


\section{Acknowledgements}

The authors gratefully acknowledge the support of the Ministry of Education and Culture of Indonesia and Universitas Negeri Semarang in providing the Research Fund (Project Number: 97.234/UN37/PPK.3.1/2020). This research is a collaboration research scheme between Universitas Negeri Semarang (UNNES), Indonesia, and Universiti Teknologi MARA (UiTM), Malaysia.

\section{References}

García, A. F., Vázquez, B. A., \& Macías, C. R. (2015). Resident's attitudes towards the impacts of tourism. Tourism Management Perspectives, 13, 33-40. https://doi.org/10.1016/j.tmp.2014.11.002

Ardika, I. G. (2018). Kepariwisataan Berkelanjutan: rintis jalan lewat komunitas. (R. B. E. A. N. Nugroho \& P. P. Giero, Eds.). Jakarta: Kompas Media Nusantara.

Baskara, K. A., Hendarto, R. M., \& Susilowati, I. (2017). Economic's valuation of marine protected area (Mpa) of Karimunjawa, Jepara-Indonesia. AACL Bioflux, 10(6), 15541568.

Campbell, S. J., Kartawijaya, T., Yulianto, I., Prasetia, R., \& Clifton, J. (2013). Co-management approaches and incentives improve management effectiveness in the Karimunjawa National Park , Indonesia. Marine Policy, 41, 72-79. https://doi.org/10.1016/j.marpol.2012.12.022

Ernawati, N. M., Sudarmini, N. M., \& Sukmawati, N. M. R. (2018). Impacts of Tourism in Ubud Bali Indonesia: A community-based tourism perspective. Journal of Physics: Conference Series, 953(1). https://doi.org/10.1088/1742-6596/953/1/012078

Eslami, S., Khalifah, Z., Mardani, A., Streimikiene, D., \& Han, H. (2019). Community attachment, tourism impacts, quality of life and residents' support for sustainable tourism development. Journal of Travel and Tourism Marketing, 36(9), 1061-1079. https://doi.org/10.1080/10548408.2019.1689224

Gladstone, W., Curley, B., \& Shokri, M. R. (2013). Environmental impacts of tourism in the Gulf and the Red Sea. Marine Pollution Bulletin, 72(2), 375-388.

https://doi.org/10.1016/j.marpolbul.2012.09.017

Hadi, S. (2004). Statistik (Jilid 2). Yogyakarta: ANDI.

Higgins-Desbiolles, F. (2017). Sustainable tourism: Sustaining tourism or something more? Tourism Management Perspectives, 25, 157-160. https://doi.org/10.1016/j.tmp.2017.11.017

Jones, P. J. S., Qiu, W., \& Santo, E. M. De. (2013). Governing marine protected areas : Social ecological resilience through institutional diversity. Marine Policy, 41, 5-13. https://doi.org/10.1016/j.marpol.2012.12.026

Kennedy, E. V., Vercelloni, J., Neal, B. P., Ambariyanto, Bryant, D. E. P., Ganase, A., ... HoeghGuldberg, O. (2020). Coral reef community changes in Karimunjawa National Park, Indonesia: Assessing the efficacy of management in the face of local and global stressors. Journal of Marine Science and Engineering, 8(10), 1-27. https://doi.org/10.3390/jmse8100760

Laksono, A. N., \& Mussadun. (2014). Dampak Aktivitas Ekowisata di Pulau Karimunjawa Berdasarkan Persepsi Masyarakat. Jurnal Teknik PWK, 3(2), 262-273. Retrieved from http://ejournal-s1.undip.ac.id/index.php/pwk

Limbong, F., \& Soetomo, S. (2014). Dampak Perkembangan Pariwisata Terhadap Lingkungan Taman Nasional Karimunjawa. Ruang, 2(1), 351-360. 
Liu, W., Vogt, C. A., Luo, J., He, G., Frank, K. A., \& Liu, J. (2012). Drivers and socioeconomic impacts of tourism participation in protected areas. PloS One, 7(4). https://doi.org/10.1371/journal.pone.0035420

Moses, J. W., \& Knutsen, T. L. (2012). Ways of Knowing: Competing Methodologies in Social and Political Research (Second Edi). New York: Palgrave Macmillan.

Nawawi, H. (2015). Metode Penelitian Bidang Sosial. Yogyakarta: Gadjah Mada University Press.

Nugroho, S. S., Harsasto, P., \& Astuti, P. (2015). Pola Kemitraan Dalam Pengelolaan Pariwisata di Kepulauan Karimunjawa Kabupaten Jepara. Journal of Politic and Government Studies, 4(1).

Nurgiyantoro, B., Gunawan, \& Marzuki. (2002). Statistik Terapan Untuk Penelitian IImu-IImu Sosial (Cetakan ke). Yogyakarta: Gadjah Mada University Press.

Pendit, N. S. (2006). Ilmu Pariwisata. Jakarta: PT. Pradnya Paramita.

Pitana, I. G., \& Gayatri, P. G. (2005). Sosiologi Pariwisata. Yogyakarta: ANDI.

Priyanto, S. E. (2016). Dampak Perkembangan Pariwisata Minat Khusus Snorkeling Terhadap Lingkungan: Kasus Destinasi Wisata Karimunjawa. Jurnal Kepariwisataan, 10(3), 12-28.

Priyanto, S. E., \& Pirastyo, S. P. (2019). What Are the Cultural Impacts From the Development of Tourism Village? THE Journal : Tourism and Hospitality Essentials Journal, 9(1), 21. https://doi.org/10.17509/thej.v9i1.16985

Puryono, S., \& Suryanti, S. (2019). Degradation of Mangrove Ecosystem in Karimunjawa Island Based on Public Perception and Management. IOP Conference Series: Earth and Environmental Science, 246(1). https://doi.org/10.1088/1755-1315/246/1/012080

Rochwulaningsih, Y. (2015). The Role of Social and Cultural Values in Public Education in Remote Island: a Case Study in Karimunjawa Islands, Indonesia. Komunitas: International Journal of Indonesian Society and Culture, 7(1), 1-16.

https://doi.org/10.15294/komunitas.v7i1.3336

Ruhanen, L., Weiler, B., Moyle, B. D., \& McLennan, C. J. (2015). Trends and patterns in sustainable tourism research: a 25-year bibliometric analysis. Journal of Sustainable Tourism, 23(4), 517-535. https://doi.org/10.1080/09669582.2014.978790

Setiawan, B., Rijanta, R., \& Baiquni, M. (2017). Poverty and Tourism: Strategies and Opportunities in Karimunjawa Island, Central Java. Journal of Indonesian Tourism and Development Studies, 5(2), 121-130.

https://doi.org/10.21776/ub.jitode.2017.005.02.08

Sudarmin, \& Pujiastuti, S. E. (2015). Scientific Knowledge Based Culture and Local Wisdom in Karimunjawa for Growing Soft Skills Conservation. International Journal of Science and Research (IJSR), 4(9), 598-604.

Tatarusanu, M. (2016). Local community involvement in tourism development. Management Intercultural, 18(37), 435-440.

Umardiono, A. (2011). Pengembangan Obyek Wisata Taman Nasional Laut Kepulauan Karimun Jawa. Komunikasi FISIP Unair, 24(4), 192-201.

Winata, A., Yuliana, E., \& Rusdiyanto, E. (2017). Diversity and natural regeneration of mangrove vegetation in the tracking area on Kemujan Island Karimunjawa National Park, Indonesia. Advances in Environmental Sciences, 9(2), 109-119. Retrieved from https://search.proquest.com/docview/2018601561 ?accountid=17242

Zhong, L., Deng, J., Song, Z., \& Ding, P. (2011). Research on environmental impacts of tourism in China: Progress and prospect. Journal of Environmental Management, 92(11), 29722983. https://doi.org/10.1016/j.jenvman.2011.07.011 